\title{
PERIPHERAL SETTLEMENTS - HOW TO CREATE A NEW IDENTITY FOR THEM - AN EXPERIMENT AS AN INITIAL POINT FOR THE FUTURE DEVELOPMENT
}

\author{
$U D C 711.42(045)=111$
}

\author{
Igor Marić \\ The Intitute of Architecture and Urbanism of Serbia, Belgrade, Serbia
}

\begin{abstract}
There are many kinds of peripheral settlements: peripheral settlements of cities, municipalities, or close to the country borders. Their genesis, position and connections are different, so that their role in the network of settlements is frequently marginalized, A general idea that these settlements are an encumbrance and that they are very often not arranged and rejected as important urban units has resulted in their significant degradation. This paper deals with their general categorization by position, size, economic and other features.

For the purpose of their revitalization, programs are proposed - experimental pilot project which would be used for future considerations in creating development strategies. Even though the experiments are often utopian and unrealistic, this paper suggests the projects which would be sustainable in terms of existing circumstances and resources. The point is to modernize the traditional values and economy and to introduce monitoring and development monitoring, to centralize and coordinate the experiment and have professionals of various specialties exchange their knowledge and experience. The focus of consideration is the development of contemporary livestock keeping and organic food oriented agriculture, as well as tourism, special services, crafts, folklore products. The basic concept is connecting the small capacities into middle sized and big systems, improvement of living conditions, specific and alternative advantages of living and working in small communities, reconstruction etc.
\end{abstract}

Key words: experiment, social care, agriculture, diversity, revitalization.

There are many kinds of peripheral settlements: : peripheral settlements of cities, municipalities, or close to the country borders. Each of them is specific in terms of their genesis, position and connections to the surrounding area and urban zones.

Peripheral settlements, outskirts of cities are in a more favorable position than the remaining two types, having in mind that they are in the close contact with the developed urban zone. Development of village settlements in such circumstances is favorable in 
terms of a market for goods, and opportunities to acquire education, find jobs and satisfy sport, cultural and other needs. The basic problem of these settlements is the absence of the exactly the contents offered by a town - by this, those settlements have insufficient elements to preserve their own identity. This kind of settlements are not endangered in the sense of extinction, but they are rather faced with a problem of their own character, which cannot be clearly expressed in those circumstances. In time, instead of building their own identity, such settlements lose it.

Management of village areas and development of their arrangement has been neglected at all the levels of management, and so also in this area when it comes to the village settlements within the territories of the cities which have General or spatial plans. The settlements on the fringes, margins of the municipalities have various destinies. Especially endangered are those located in the areas whose borders are in the mountainous regions. A characteristics example is the municipality of Rekovac which is surrounded with Gledic mountains, and the settlements on its borders are being rapidly depopulated.

The gravest problems in this vein are visible in border regions, especially in the mountainous ones. Thus out of 57 border municipalities, 20 are labeled as underdeveloped regions. On the basis of the Law of underdeveloped regions, the belt of $15 \mathrm{~km}$ alongside the state border is proclaimed underdeveloped in all of the 57 border municipalities.

Particularly concerning is the value of the investigated indicators for the border municipalities of the central part of Serbia, which are considerably worse than the average of the Republic, especially in respect to the border belt of Vojvodina which is incomparably better. The industrialization and urbanization process had a negative impact on the development of these village settlements in terms of their depopulation and loss of principal characteristics. ${ }^{1}$

Occasional partial and uncoordinated sector activities at a Republic or local management level, are inefficient from the point of view of development, organization, arrangement and protection of village areas and settlements. In essence, it is clear that this complex issue is of strategic importance for preservation of the territory and development of social community, but it is left to an initiative and self-organization of the population in village settlements. ${ }^{2}$

On the basis of the stated facts, several fundamental questions arise: which are the minimal conditions to survive normally in the marginal areas. Should marginal areas bi used for living at all, or they should be arranged and used in some other, different way? In some other questions, the second question is already is not topical, since there are deserted settlement in the border areas, such as Ćuštica in Knjaževac municipality, or settlements with almost entirely aged households such as Dojkinci in the municipality of Pirot, Gostuša and Senokos in the municipality of Dimitrovgrad (Figures 1,2 and 3).

\footnotetext{
${ }^{1}$ Malobabić R., Dabić D., Korišćenje resursa, održivi razvoj i uređenje prostora, IAUS, posebna izdanja 1997, 318.

${ }^{2}$ Maksin-Mčić M., Milijić S., Selo u novim razvojnim uslovima, UUS, Beograd 2002, 135.
} 


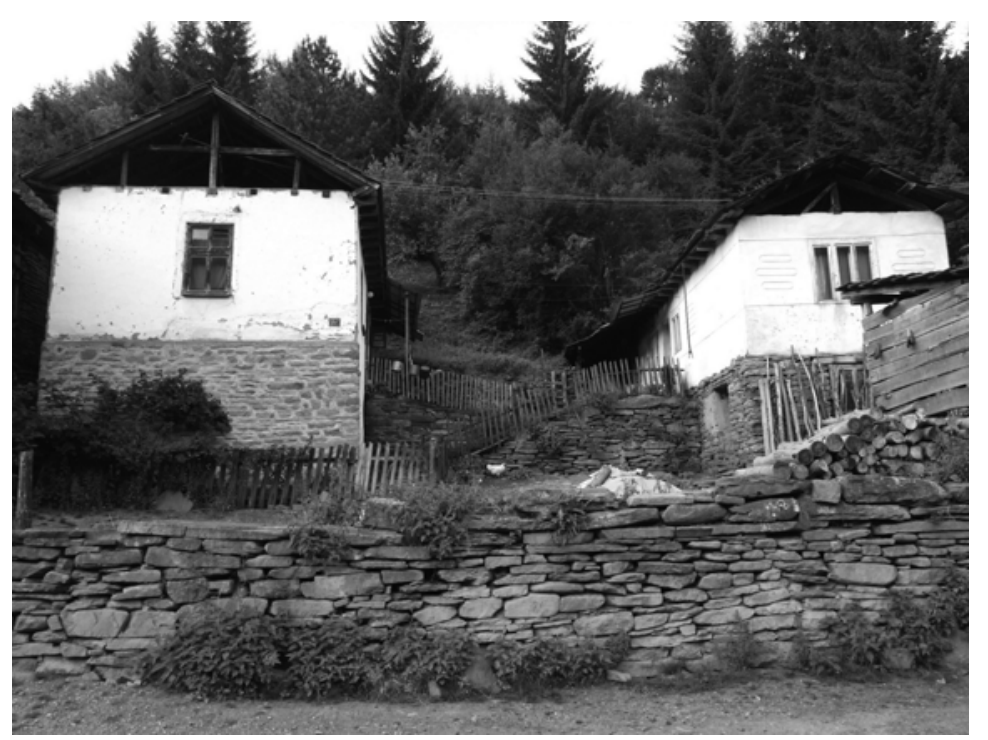

Fig. 1. Village Dojkinci - Community Pirot

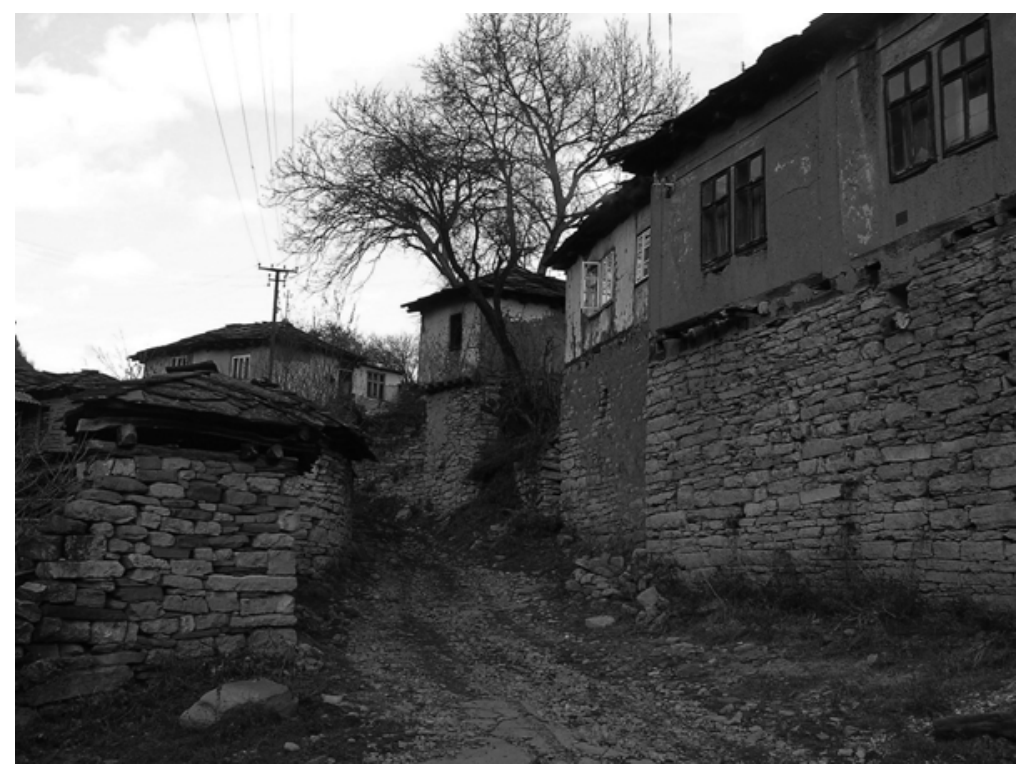

Fig. 2. Village Gostuša - Community Dimitrovgrad 


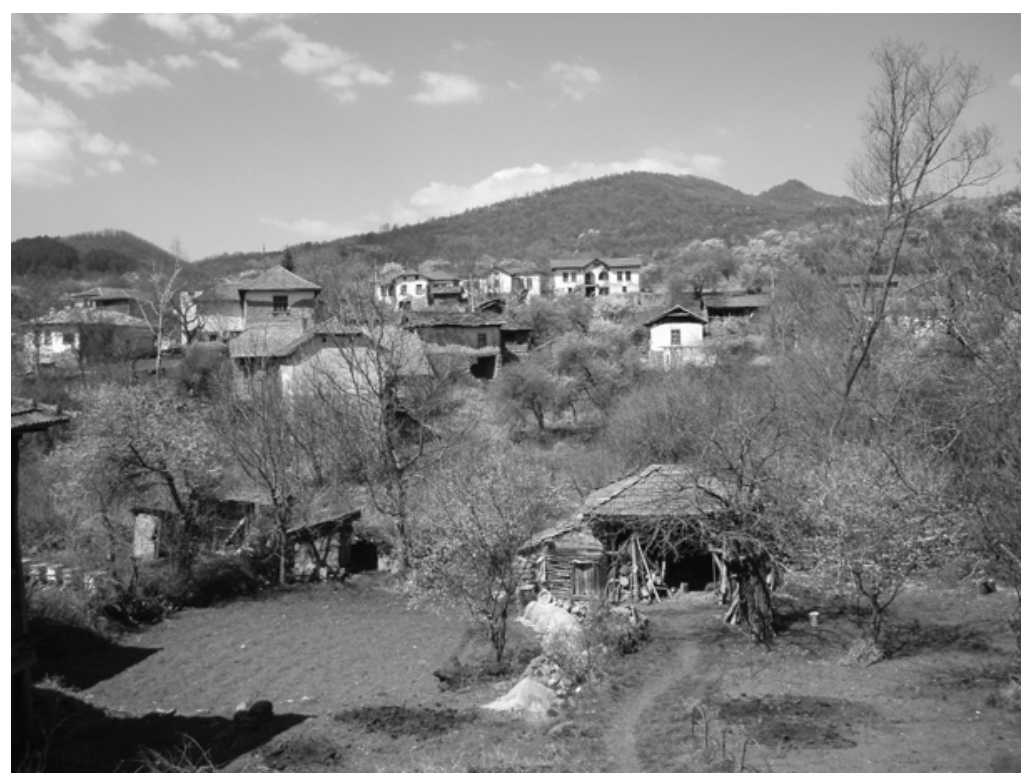

Fig. 3. Village Senokos - Community Dimitrovgrad

Since government exhibits almost unreasonable disinterestedness for radical moves and new strategies in the future, unless something has been done, soon there will be an abandoned territory and an untilled soil and waste where once was life.

In the absence of significant planning or practical actions, it would be desirable to, at least, do experimental projects which would be based on the international experiences and local characteristics.

In national circumstances the most frequently applied development models of these areas are the tourist zones. Some of these projects developed and some are being developed, but insufficiently. It is certain that tourism is a valuable additional activity which generates other activities in the field of infrastructure, trade, retail sales, culture. In principle, in order to preserve these village communities, it is necessary to enable the population to have multiple occupations. Marginal settlements in the municipalities and border settlements are scattered and small, and infrastructure construction in such regions is very expensive. As opposed to the marginal settlements of the towns, town-working population would not settle in those places and would not engage in agriculture.

It is possible to preserve a number of settlements through the planned development of alternative activities which would primarily be - tourism, then some aspects of small scale primary processing, gathering and processing of medicinal herbs, timber industry, crafts etc. Also, the fact that some settlements will be entirely deserted has to be accepted, meaning that such areas should be activated in some other way. Firstly, the deserted land should be bought off by the state or a person with the assistance of the state and integrate it, and then use it according to plan. Depending on the territory, the space can be reforested for commercial exploitation, or intended for livestock keeping or farming, or to make the hunting grounds and intact nature zones for excursion tourism etc.

The state, or an association of the stockholders who would obtain certain long-term privileges, should conduct experimental projects in the characteristic areas. In some 
places, some traditional crops could be cultivated, and in some places entirely new ones should be tried. A good example is revitalization of Rajac alehouses (figure 4) which were almost totally extinct, or the example of Sirogojno with a revived weaving tradition and ethno-village construction (figure 5).

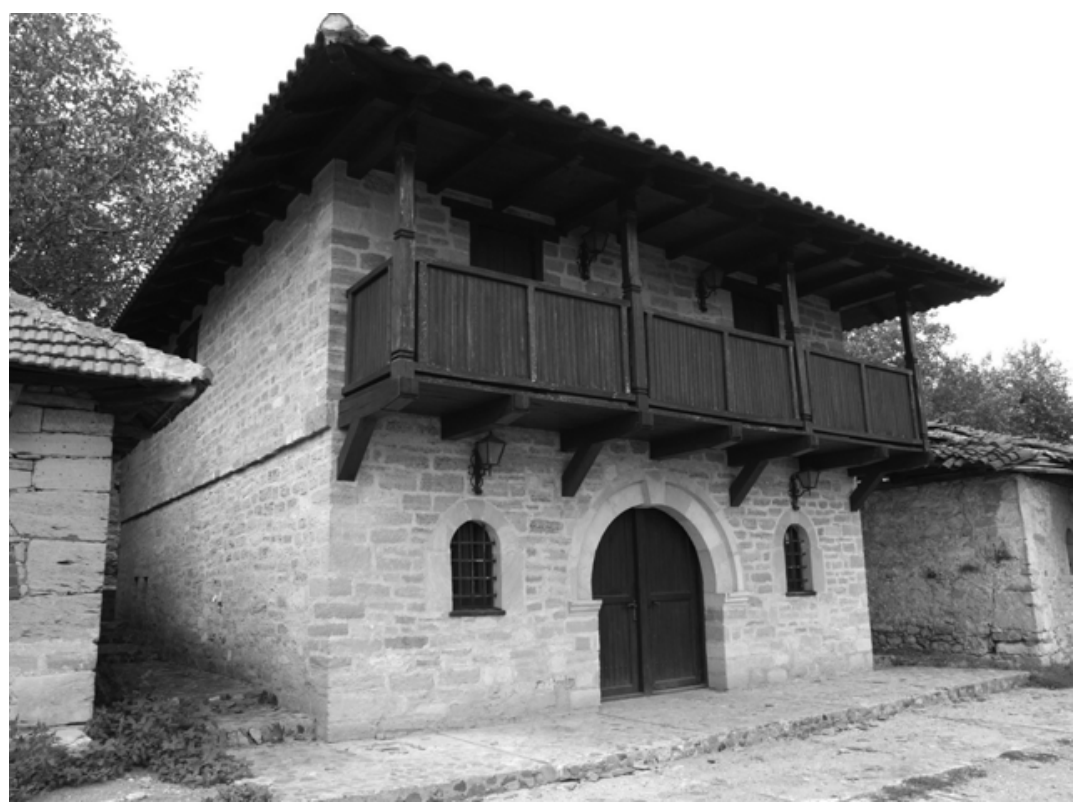

Fig. 4. Rajačke pivnice

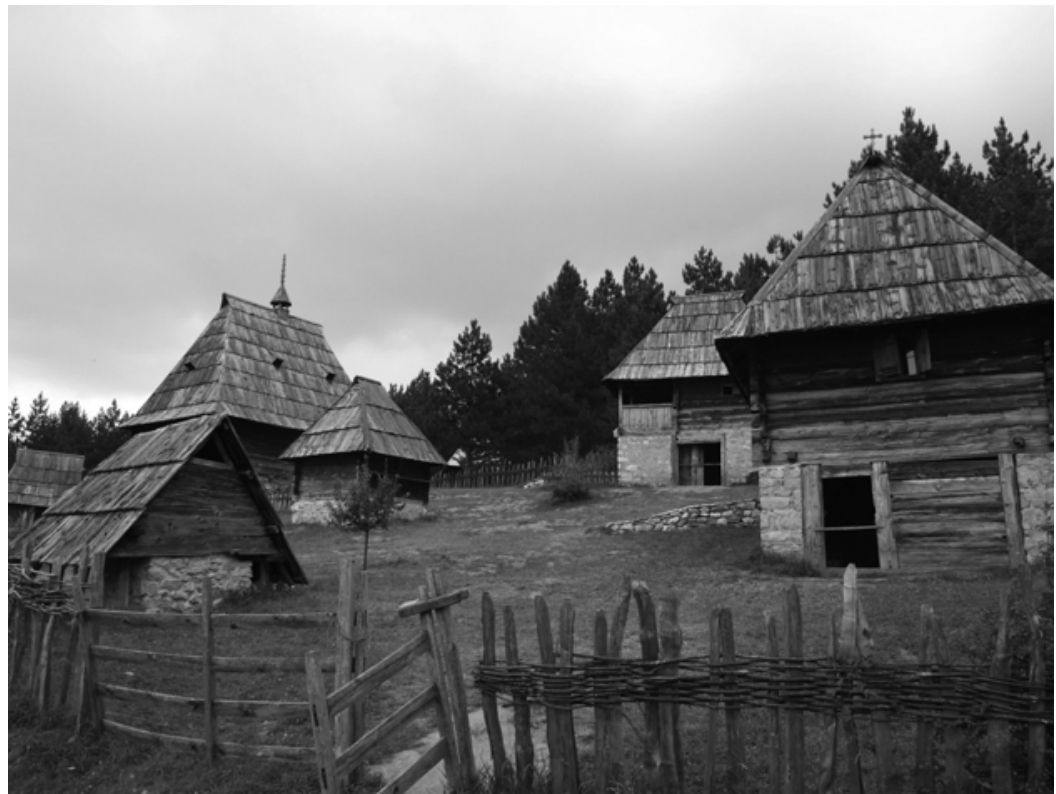

Fig.5. Village Sirigojno 
Technological updating of village households would certainly significantly assist in marginal areas settlement survival. A general tendency is evident in the industrially developed countries too, where despite all the effort the village population dwindling is obvious. In this sense, the changes in the village network are necessary, of their number and size. As opposed to these settlements, the village settlements on the peripheries of large cities are enlarging, very of then exactly with the population which left the peripheral settlements of municipalities and the country. It is often the case that entire parts of the settlements move into enclaves similar to those from which the settlers come. These spontaneous migrations are not controlled by the state, so this issue should be addressed with test projects which would enable that such settlements are not the parasites of the city, but to gain their own identity. This could be accomplished through an town planning design, central contents, green surfaces, commercial zones etc. the most important thing would be to equip them with infrastructure, or to at least reserve the corridors for later construction.

\section{CONCLUSION}

Diversity of natural and socio-economic circumstances, complexity and mutual dependence of the problems and their causes, require complex and comprehensive procedures entailing integration of several professions. It is of crucial importance to animate the state apparatus to take radical measures concerning villages and their development, an issue which is nowadays pushed aside. It would be necessary to conduct a long-term priority policy:

- Organized care for the population of peripheral settlements, in the form of the mobile medical units, public utilities services, transport of school children, various kinds of education etc. All these services should reach out to the endangered peripheral areas, and not forcing population to visit towns to get advice and help.

- Organization of centers for several small villages

- Continuous combat against poverty through education and giving assistance, particularly in female and young population.

- Using of alternative advantages of village life with clean environment.

- Development of infrastructure and usage of alternative energy sources: solar, wind, water, biogas, etc.

- Insistence on taking part in multiple activities, diversification of agriculture and development of food processing industry.

- Stimulation of enlarged farming land and prohibition of atomization of inherited land.

- Stimulation of tourism, agro - tourism, hunting, fishing and usage of natural and cultural rarities for affirmation of the region.

- Making programs for experimental action: restructuring of settlements, grouping, construction on new locations, carrying out programs of massive extensive cattle breeding, controlled by modern technological instruments.

- Networking of households, through electronic communication, with similar activities within small spatial units. 
- Reduction of social conflicts so that various forms of partnership between village and town, villagers and capital owners, locals and newcomers etc could be enabled.

- New approaches to the arrangement of the village households and rational construction of buildings based on the tradition and usage of modern technologies.

\section{REFERENCES}

1. Fedorenko Marić I., Transformacija narodne arhitekture Centralne Srbije u procesu urbanizacije u XIX i XX veku, doktorska disertacija, Beograd 2006.

2. Marić I., Urbanistički planovi naselja u prirodnim predelima, u monografiji Planiranje i uređenje predela, Udruženje urbanista Srbije, Beograd 1996.

3. Maksin - Mićić M., Zaštita i rezervisanje prostora, normativnost i poraksa, Univerzitet u Beogradu, Geografski fakultet, Beograd 2000.

4. Održivi prostori, urbani i ruralni razvoj Srbije, Zbornik radova sa naučnog skupa, IAUS, Beograd 2004.

5. Selo u novijim razvojnim uslovima, Zbornik sa naučnog skupa, Udruženje urbanista Srbije, Beograd 2002.

6. Korišćenje resursa, održivi razvoj i uređenje prostora, IAUS, Posebna izdanja, Beograd 1997.

7. Strategija razvoja i uređenje naselja u novim uslovima, Udruženje urbanista Srbije, Beograd 1998.

\section{RUBNA NASELJA I KAKO IM STVORITI NOVI IDENTITET - EKSPERIMENT KAO POLAZIŠTE ZA BUDUĆI RAZVOJ \\ Igor Marić}

Rubna naselja imamo raznih vrsta: rubna naselja gradova, opština, ili na granicama država. Različitia su: geneza, položaj i veze tako da je i njihova uloga u mreži naselja često marginalizovana. Uopšteno shvatanje da su ta naselja nužno opterećenje i često neuređena $i$ neprihvaćena kao značajne urbane celine je dovela do njihove degradacije. Ovim radom tretira se njihova opšta kategorizacija po položaju, veličini, privrednom i drugim odlikama.

Radi njihove revitalizacije predlaču se programi koji podrazumevaju eksperiment (pilot projekt) koji bi slučio za moguća zaključivanja pri formiranju strategija razvoja. Iako su eksperimenti često utopijski i nerealni ovim radom se predlaču projekti koji bi bili odrčivi u smislu postojećih okolnosti $i$ resursa. Poenta je na osavremenjavanju tradicionalnih vrednosti $i$ privređivanja, uvođenje monitoringa i praćenja razvoja, centralna koordinacija eksprementa $i$ prenošenje saznanja sa različitih područja i iskustava u međusobnoj razmeni. U osnovna polja razmatranja spadaju razvoj savremenog stočarstva i poljoprivrede sa osloncem na zdravoj hrani, turizmu, specijalnim uslugama, zanatstvu, narodnoj radinosti. Osnovni pojam je umrečavanje malih kapaciteta u srednje $i$ velike sisteme, poboljšanje uslova čivota, specifične i alternativne prednosti čivota i rada u manjim sredinama, rekonstruktivni zahvati i drugo. 